\title{
ACKNOWLEDGEMENT OF PRIORITY TO "A CHARACTERIZATION OF THE VON MISES DISTRIBUTION"
}

\author{
By Louis Gordon and Malcolm Hudson \\ Department of Energy and Macquarie University
}

We are grateful to Professor D. G. Kendall for drawing to the authors' attention the precedence of Professor G. E. H. Reuter (unpublished work) in establishing the result of our note [Ann. Statist. (1977) 5 813-814]. The result appeared in the discussion on page 416 of Professor Kendall's paper [J.Roy. Statist. Soc. Ser. B (1974) 36 365-402] although in our references this paper was incorrectly attributed to M. G. Kendall.

P.O. Box 171

Benjamin Frankin Station

WASHINGTON, D.C. 20044
MACQUARIE UNIVERSITY

SCHOOL OF ECONOMIC AND FinanCial StUdies North Hyde, New South Wales 2113

Australia

Received March 1978.

AMS 1970 subject classifications. Primary 62E10; secondary 60J65.

927 